\title{
Queen honey bee introduction and early survival - effects of queen age at introduction
}

\author{
John W. RHODES ${ }^{\mathrm{a} *}$, Douglas C. SOMERVILLE ${ }^{\mathrm{b}}$, Steven HARDEN ${ }^{\mathrm{a}}$ \\ a NSW Agriculture, RMB 944, Tamworth, New South Wales, 2340, Australia \\ b NSW Agriculture, PO Box 389, Goulburn, New South Wales, 2580, Australia
}

(Received 15 April 2003; revised 12 September 2003; accepted 8 October 2003)

\begin{abstract}
The survival of honey bee Apis mellifera queens to 14 days and 15 weeks after introduction into an established bee colony increases with increasing age of the queen at introduction. Survival rates increased strongly to high levels for queen bees introduced between 7 and 24 days of age and at a slower rate for queens introduced at ages up to 35 days. The survival rates were similar for sister queens introduced into two unrelated apiaries suggesting that apiary site and beekeeper management differences had minimal effect on survival rates. A year effect was found but the response to increasing age was similar for the three years.
\end{abstract}

\section{Apis mellifera / queen age / queen introduction / queen survival}

\section{INTRODUCTION}

Over recent years commercial honey producers in Australia have reported that the numbers of commercially reared queen bees surviving introduction into established honey production hives are often low, or they may have a satisfactory introduction survival rate but poor performance by the surviving queen bees. Similar problems have been reported in North America (Camazine et al., 1998; Bach, 1993 ) with a number of possible causes being suggested.

One factor not discussed is the effect of queen age at introduction. Little or no data are available on the earliest age that queen bees can be introduced into established bee colonies to provide the highest introduction and early survival success rates. To provide data on this subject a three year study, 1999-2001, investigated introduction and early survival success rates of commercially reared queen bees.

This paper discusses queen bee survival rates of sister queen bees caught from their mating nucleus or from a queen bank at a range of ages between 7 and 35 days of age and introduced into established bee colonies 36-48 h after being caught.

\section{MATERIALS AND METHODS}

\subsection{Queen bees and apiaries}

A commercial queen bee breeder based in south eastern Queensland provided queen bees for the three years of the project. Two commercial honey producers based in the south eastern (Apiary A) and in the north western (Apiary B) districts of New South Wales provided commercially managed honey production apiaries for queen bee evaluation each year. The three locations represent widely different climate zones.

Sufficient numbers of test queen bees for each year's experiments were reared at the considered peak queen bee production time (October-November) from two sister (year 1) and one (years 2 and 3 ) Italian race type Apis mellifera II breeder queen bees. Different breeder queens were used each year, all were provided from a breeding program utilising homogenised semen in its II program. All queen cells were grafted on the same day, reared in colonies

\footnotetext{
* Corresponding author: john.rhodes@agric.nsw.gov.au
} 
in the same cell rearing apiary, and all queens were mated in the same queen mating apiary at the same time each year. Queen bees caught at 7 days of age had not commenced laying while all queen bees caught at 14 days and older had commenced laying. Drone mother colonies were managed to provide mature age drones at the time test queens were expected to be mating. Queen mating apiaries were encircled by drone mother colonies distributed at three sites 2.3, 1.5 and $1.0 \mathrm{~km}$ from the mating apiary.

Each commercial honey producer provided a 100 hive apiary which required requeening each year of the experiment.

\subsection{Field project}

\subsubsection{Queen age at introduction}

For years 1 and 2 (1999 and 2000), queen bees were caught from their mating nucleus at 7, 14, 21, 28 and 35 days of age. Twenty queens of each age were sent to each of the two honey producers.

For year 3 (2001), some queen bees were caught from their mating nucleus at 17, 24 and 31 days of age, and others were caught at 17 days of age, placed in a queen bank for 7 or 14 days, and taken from the queen bank and introduced into honey production hives at 24 and 31 days of age. Twenty 17 day old queens were sent to the two honey producers. For 24 and 31 day old queens, the two honey producers each received 20 queens caught from their mating nucleus and 20 queens taken from the queen bank.

Queens bees caught from their mating nucleus were marked on the thorax with a Posca ${ }^{\circledR}$ water based marking pen at 7,14 or 17 days of age, queen bees placed in the queen bank were marked on removal from the queen bank.

For the purpose of this paper, the age queen bees were caught from their mating nucleus or queen bank is referred to as the Introduction Age. In practice, following transport time between the queen bee breeder and the honey producer, all queen bees were physically introduced into bee colonies between 36 and $48 \mathrm{~h}$ after being caught from their mating nucleus or queen bank.

\subsubsection{Queen introduction}

Queen bees were subjected to the normal management practices used by each honey producer when receiving and introducing queen bees - in Apiary A, queen bees were introduced in Benton type mailing cages with six escort bees present and in Apiary B, Miller type introduction cages were used with the escort bees removed. Queen candy used in the Benton type mailing cages was manufactured by the queen bee supplier and a commercial brand queen candy was used in the Miller type cages.

\subsubsection{Queen survival and performance data}

Data were collected on queen bee survival to provide the following information:

- Introduction Survival Success (ISS) - all hives which had a marked queen introduced were examined 14 days after introduction and the presence or absence of the marked queen recorded.

- Early Survival Success (ESS) - all hives containing a marked queen 14 days after introduction were examined a second time 15 weeks after the queen introduction and the presence or absence of the marked queen recorded.

\section{RESULTS}

Queen bee survival data for 1999, 2000 and 2001 are shown in Table I with fitted curves for Introduction Survival Success and Early Survival Success shown in Figure 1.

The data on ISS and ESS are the proportion of queens of varying age surviving to 14 days and 15 weeks after introduction into established bee colonies and are therefore binomial in nature. These binomial data were analysed as a generalised linear model using the $\operatorname{glm}()$ function in the statistical software package S-Plus (Mathsoft, 1999) using the logistic function $\log (\mathrm{p} /(1-\mathrm{p}))$ which ensures predicted proportions remain in the 0 to 1 interval, together with a binomial variance function $\mathrm{p}(1-\mathrm{p})$ and using the number of queens (n) tested as weights. A logistic regression of the proportion of queens surviving (ISS and ESS) with Age at introduction (AGE) as the only independent variable gave a poor fit. The fit was greatly improved with the addition of the term $\mathrm{AGE}^{\wedge} 2$ to accommodate curvature in the regression and the terms APIARY and YEAR were included in the model to account for differences due to apiary and year. The significance of a term in the model can be tested using the deviance statistic $\mathrm{D}=2$ (LL1 - LL2), (McCullagh and Nelder, 1989) where LL1 is the log-likelihood of the model containing the term and LL2 is the loglikelihood of the model with the term excluded. The deviance statistic has an approximate $\chi_{\mathrm{df}}^{2}$ distribution, where df is the difference in the number of parameters fitted, and terms are significant for $\mathrm{df}=1$ at the $5 \%$ level if $\mathrm{D}>3.84$. The significant terms together with their deviance statistics for ISS and ESS were AGE (128.6, 87.9), $\mathrm{AGE}^{\wedge} 2(9.6,9.4)$ and YEAR 
Table I. Number of queen bees present for ISS and ESS by apiary and by age group $(n=20)$.

\begin{tabular}{|c|c|c|c|c|c|c|c|}
\hline \multirow{3}{*}{$\begin{array}{l}\text { Date queens } \\
\text { caught }\end{array}$} & \multirow{3}{*}{$\begin{array}{c}\text { Age of queen } \\
\text { when caught } \\
\text { (days) }\end{array}$} & \multicolumn{6}{|c|}{ Number of queen bees present in hives } \\
\hline & & \multicolumn{3}{|c|}{ Introduction Survival Success** } & \multicolumn{3}{|c|}{ Early Survival Success } \\
\hline & & A & B & Total \% & A & B & Total \% \\
\hline \multicolumn{8}{|l|}{1999} \\
\hline 10.11 & $7 \mathrm{~m}$ & $2^{*}$ & 4 & 15.4 & $1^{*}$ & 3 & 10.3 \\
\hline 17.11 & $14 \mathrm{~m}$ & 10 & 9 & 47.5 & 3 & 3 & 15.0 \\
\hline 24.11 & $21 \mathrm{~m}$ & 15 & 19 & 85.0 & 9 & 16 & 62.5 \\
\hline 1.12 & $28 \mathrm{~m}$ & 18 & 16 & 85.0 & 11 & 13 & 60.0 \\
\hline 8.12 & $35 \mathrm{~m}$ & 20 & 16 & 90.0 & 14 & 15 & 72.5 \\
\hline \multicolumn{8}{|l|}{2000} \\
\hline 17.11 & $7 \mathrm{~m}$ & 5 & $6^{*}$ & 28.2 & 4 & $6^{*}$ & 25.6 \\
\hline 23.11 & $14 \mathrm{~m}$ & 15 & 13 & 70.0 & 15 & 13 & 70.0 \\
\hline 30.11 & $21 \mathrm{~m}$ & 15 & 17 & 80.0 & 14 & 15 & 72.5 \\
\hline 7.12 & $28 \mathrm{~m}$ & $18^{*}$ & 19 & 94.9 & $18^{*}$ & 16 & 87.2 \\
\hline 14.12 & $35 \mathrm{~m}$ & 18 & 20 & 95.0 & 16 & 19 & 87.5 \\
\hline \multicolumn{8}{|l|}{2001} \\
\hline 23.11 & $17 \mathrm{~m}$ & 15 & $11^{*}$ & 66.7 & 15 & $11^{*}$ & 66.7 \\
\hline 29.11 & $24 \mathrm{~m}$ & 18 & 19 & 92.5 & 16 & 19 & 87.5 \\
\hline 29.11 & $24 \mathrm{~b}$ & 13 & 14 & 67.5 & 13 & 14 & 67.5 \\
\hline 6.12 & $31 \mathrm{~m}$ & 17 & 18 & 87.5 & 15 & 17 & 80.0 \\
\hline 6.12 & $31 \mathrm{~b}$ & 18 & 18 & 90.0 & 17 & 16 & 82.5 \\
\hline
\end{tabular}

* out of $19 \quad \mathrm{~m}$ caught from mating nucleus

$* *$ introduction age $=$ age caught +36 to $48 \mathrm{~h}$

A apiary A B apiary B

$(12.9,44.6)$. The deviance statistics for APIARY and the interaction terms of AGE and $\mathrm{AGE}^{\wedge} 2$ with YEAR and APIARY were small and these terms were not significant. The terms for the final model were YEAR + AGE + $\mathrm{AGE}^{\wedge} 2$.

This final model implies that survival rates are a function of age with survival rates being lower in some years but having a similar response to age in each of the three years, while there were no significant differences due to the apiaries used.

The predictions are for the average over the three years of the experiment. The predicted values and SE's for ISS at 7, 14, 21, 28 and 35 days were 21.0 (5.5), 58.6 (5.6), 82.2 (3.6), 90.1 (2.2) and 91.6 (3.0) percent survival, for ESS they were 19.9 (5.2), 48.2 (5.0), 69.5 (4.3), 79.0 (3.2) and 80.6 (4.3) percent survival. The curvilinear response to age indicates that while survival rate increases over the interval 7 to 35 days, the rate of increase in survival rate decreases as age increases. Most increase occurs before 28 days. Note that data for queens caught from a queen bank were not included in the analysis because they were collected only in 2001 for queen bees aged 24 and 31 days.

When data from the non egg laying queens were omitted and the models refitted the predicted values and SE's for ISS at 14,21, 28 and 35 days were 57.6 (7.0), 82.6 (3.9), 90.4 (2.4) and 91.3 (3.3) percent survival, for ESS they were 47.7 (6.4), 69.6 (4.5), 79.2 (3.6) and 80.4 (4.5) percent survival. The response of survival rate to increasing age is similar to the response obtained when data for the egg laying and non egg laying queens were used to fit the curve.

\section{Other factors}

Climate, foraging (availability of nectar and pollen) and general hive conditions during the production of experimental queens and for both commercial honey production apiaries for the duration of the 1999, 2000 and 2001 projects were average to very good. Although 1999 provided the best overall foraging conditions, queen survival rates were lowest. 


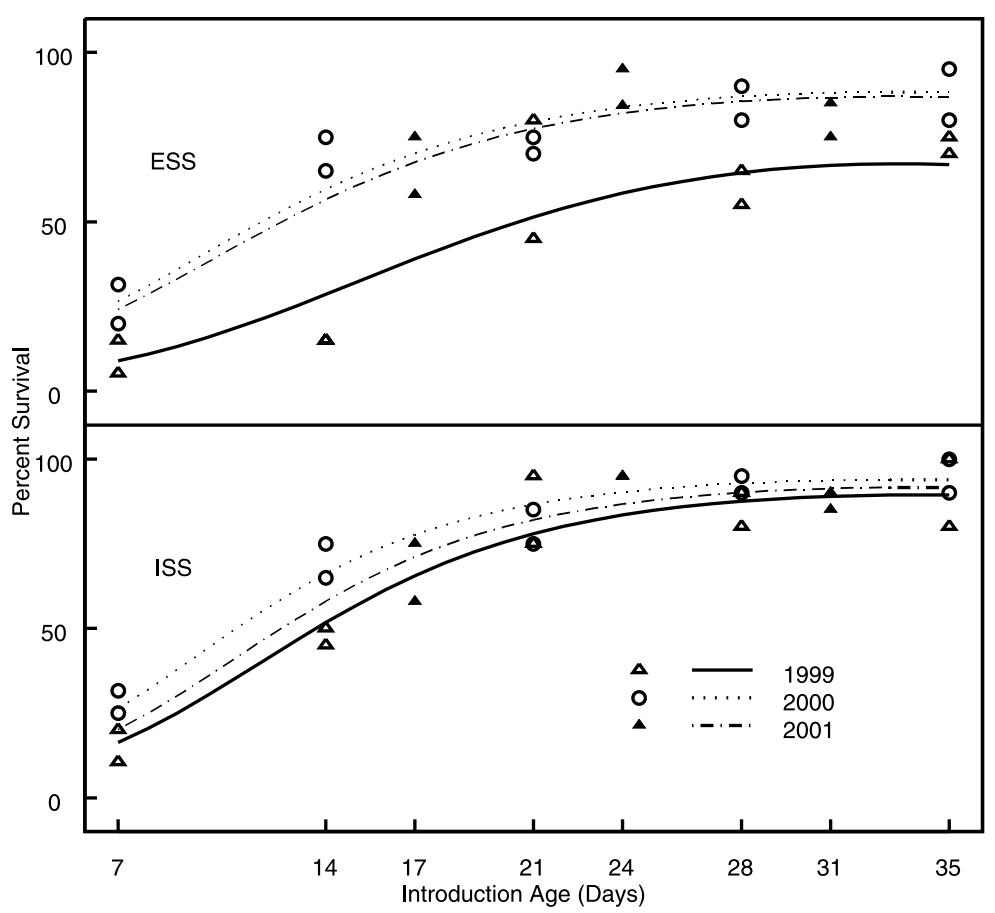

Figure 1. Fitted curves for ISS and ESS for years 1999, 2000 and 2001.

\section{DISCUSSION}

Based on the number of queen bees surviving the first 14 days following introduction, and supported by the number of queens surviving 15 weeks after introduction, the accepted beekeeping management practice of catching queen bees from their mating nucleus at between 14 and 21 days of age for immediate introduction into established bee colonies on arrival at their destination must be questioned.

For this experiment, the highest introduction survival rate obtained was $92.5 \%$ for 35 day old queens 14 days after introduction which is less than the $100 \%$ ideal success rate indicating that factors not covered by this experiment are also involved in introduction survival.

The small survival advantage av. $2.5 \%$ from holding queen bees from 28 days to 35 days before catching suggests that from a practical beekeeping management aspect, the earliest age to catch queens from their mating nucleus for introduction into established bee colonies is about 28 days of age.

The 2001 experiment attempted to determine whether queen bees caught from their mating nucleus at a young age and held in a queen bank to age them before introduction into established bee colonies was as effective as holding queens in their mating nucleus. Results were inconclusive, data obtained suggest that catching queen bees from their mating nucleus at 17 days of age and holding them in a queen bank to an age between 24 and 31 days may be a satisfactory and less expensive method for aging queen bees prior to introduction into established bee colonies but the survival rates appeared slightly lower than aging them to the same age in the mating nucleus. This management procedure requires further investigation.

Seven day old queens had not commenced laying when caught, this factor may be reflected in the large introduction survival differences between 7 day old and older queens which had commenced laying when caught. The response of survival rate to increasing age when data from the 7 day old non egg laying queens were omitted is similar to the response obtained when data for egg laying and non egg laying queens were used suggesting that increased survival can be attributed to increased age and not whether the queens were laying or non laying when caught prior to shipping. 
Under the conditions of this experiment the low survival rates 14 days after introduction demonstrate that 7,14 and 17 days are not satisfactory ages to catch queens for introduction into established colonies. For queen bees caught from their mating nucleus at 21 days of age the survival rate 14 days after introduction averaged $82.5 \%$ which was improved further to an average of $90 \%$ for queen bees caught at 28 days of age.

The benefits from increased numbers of queen bees surviving the introduction process were retained with increased numbers of queens surviving 15 weeks after introduction.

There were no significant differences between survival rates for queen bees of each age group introduced into bee colonies at either Apiary A or Apiary B, suggesting that apiary site and beekeeper management differences had minimal effects on survival rates.

The project identified a year effect on queen bee survival following introduction. Data from the 1999 season provided lower queen survival across all age groups of queen bees (Tab. I, Fig. 1). Queen bees used each year were sister queens reared from related but different II queen mothers. Seasonal effects and genotypic differences between each year's queens would have contributed to the lower survival rate recorded in 1999.

Test queen bees were reared at the same time and introduced over a number of weeks. For each year's test queens, rearing conditions were constant but introduction conditions may have varied. There was no significant difference in survival rates between queens introduced at the two climatically separated apiaries used each year suggesting that conditions at introduction had minimal effect on queen survival.

Beekeepers can expect an economic benefit from introducing queen bees that are 28 days of age or older. The benefit derives from reducing queen loss in colonies 15 weeks after introduction from $30.5 \%$ when queens are caught at 21 days to $21 \%$ for queens caught at 28 days. Costs to the beekeeper when purchasing and introducing young queens into bee colonies are relatively low when compared with benefits provided from requeening (Mangum, 1997). Costs to the beekeeper when requeening increase substantially when an introduced queen bee fails to be accepted or is superseded a short time after being accepted.
Colony population can decline rapidly during queen replacement and for several weeks afterwards (Tarpy et al., 2000). Increased costs result from replacement queen costs, travel and labour costs involved in requeening a colony in which queen removal was not controlled by the beekeeper, and loss of colony population growth and production following an uncontrolled period without a queen.

Improved survival benefits from introducing queen bees at an older age should encourage beekeepers to select queen bees that are 28 days of age or older at introduction in their requeening management programs.

\section{ACKNOWLEDGEMENTS}

We wish to thank Laurie, Paula and Robert Dewar, Aratula, Queensland, Bob, Marie, Rob and Raelene Michie, Tamworth, New South Wales and Noel and Neil Bingley, Queanbeyan, New South Wales for providing queen bees and commerical apiaries for the project and for their assistance and support. We would like to thank Dr. Arthur Gilmour, NSW Agriculture, for helpful comments when revising the manuscript.

The project was funded by the Honey Bee Program, Rural Industries Research and Development Corporation, Canberra, Australia. The New South Wales Department of Agriculture provided staff and facilities.

Résumé - Influence de l'âge de la reine d'abeilles sur le taux de survie après introduction. Ces dernières années les producteurs commerciaux de miel ont signalé que les reines d'abeilles (Apis mellifera L.) du commerce avaient souvent un faible taux de survie lorsqu'elles étaient introduites dans les ruches ou qu'elles pouvaient avoir un taux de succès satisfaisant à l'introduction mais qu'ensuite les performances de la reine étaient faibles. Chaque année les reines produites commercialement au Queensland (Australie) ont été transportées et introduites dans des colonies en production de miel appartenant à un ou deux producteurs de miel expérimentés et ce, dans diverses régions climatiques des New South Wales. Chaque année un certain nombre des reines tests ont été élevées à partir d'une ou de deux larves de reines sœurs de race italienne. Les cellules royales ont été greffées le même jour, élevées dans des colonies du même rucher d'élevage et les reines se sont accouplées dans le même rucher de fécondation. Il y avait un nombre suffisant de colonies possédant des mâles. On a prélevé dans les nucleus de fécondation les reines à l'âge de $7,14,21,28$ et $35 \mathrm{j}$ en 1999 et 2000 et à l'âge de 17, 24 et $31 \mathrm{j}$ en 2001 . En 2001 d'autres reines âgées de 17 jours ont été placées dans une banque à reines durant 7 ou $14 \mathrm{j}$, puis introduites dans les colonies de production à l'âge de 24 
ou 31 j. Pour chaque groupe d'âge on a noté le nombre de reines survivantes à $14 \mathrm{j}$ (succès d'introduction) et à 15 semaines (succès de survie) après l'introduction. A partir des données des trois saisons (1999-2001) un modèle de calcul a été mis au point. Il a montré que le succès d'introduction et le succès de survie sont très faibles pour les reines introduites à l'âge de $7 \mathrm{j}$, qu'ils augmentent avec l'âge d'introduction jusqu'à l'âge de $24 \mathrm{j}$, puis se stabilisent. Le modèle a prédit des taux de survie élevés pour les reines introduites à plus de $28 \mathrm{j}$. Des taux de survie semblables ont été trouvés pour des reines sœurs prélevées à un âge compris entre 7 et $35 \mathrm{j}$ et introduites dans deux ruchers non apparentés, ce qui suggère que le rucher et les techniques de conduite de l'apiculteur n'ont eu qu'un faible effet sur ce facteur. Un effet année a été trouvé avec des taux de survie plus faibles en 1999 mais l'allure des courbes était la même pour les trois années. Les apiculteurs peuvent donc attendre un avantage économique s'ils introduisent des reines âgées de plus de $28 \mathrm{j}$. Les prédictions du modèle montrent que le taux de survie des reines, introduites à l'âge de $28 \mathrm{j}$ est supérieur $14 \mathrm{j}$ plus tard de 32 et $8 \%$ comparé à celui d'abeilles introduites à l'âge de 14 ou $21 \mathrm{j}$, respectivement. Quinze semaines après l'introduction le taux était supérieur de 31 et $10 \%$. Si les reines sont introduites à l'âge de $35 \mathrm{j}$, le taux de survie n'est supérieur que de $2 \%$ par rapport à des reines introduites à l'âge de $28 \mathrm{j}$.

Apis mellifera / introduction / âge de la reine / taux de survie

Zusammenfassung - Der Einfluss des Königinnenalters auf die Überlebensrate nach der Einweiselung. In den letzten Jahren wurde von kommerziellen Königinnenzüchtern berichtet, dass Zuchtköniginnen nach dem Einweiseln in Völker eine geringe Überlebensrate haben, oder dass nach zufriedenstellendem Einweiseln ihre Leistungen schlecht waren. In den Jahren 1999, 2000 und 2001 wurde nach den Ursachen geforscht. In jedem Jahr wurden in Queensland kommerziell gezüchtete Königinnen in etablierte Wirtschaftsvölker eingeweiselt und von zwei erfahrenen kommerziellen Honigproduzenten in zwei klimatisch unterschiedlichen Regionen von New South Wales betreut. Jedes Jahr wurden am selben Tag Larven von ein oder zwei Apis mellifera ligustica Geschwisterköniginnen in Weiselzellen umgelarvt, am selben Zuchtstand aufgezogen und zur selben Zeit an derselben Belegstelle zur Begattung aufgestellt. An den Belegstellen gab es eine ausreichende Zahl von Drohnenvölkern. In den Jahren 1999 und 2000 wurden die Königinnen im Alter von 7, 14, 21, 28 und 35 Tagen, im Jahr 2001 im Alter von 17, 14, 21 und 28 Tagen aus den Begattungskästen entnommen. Außerdem wurden 2001 Königinnen im Alter von 17 Tagen in eine Königinnenbank gegeben, aus der sie im Alter von 24 bzw. 31 Tagen wieder entnommen wurden. Für jede der Altersgruppen wurde registriert, wie viele Königin- nen das Einweiseln 14 Tage überlebten (Einweiselerfolg) und wie viele 15 Wochen überlebten (früher Überlebenserfolg). Weiter wurde die (zufriedenstellende) Leistung der Königinnen in der 15 . Woche nach dem Einweiseln registriert. Aus den über die drei Jahre 1999-2001 erhaltenen Daten wurde ein Rechenmodell entwickelt. Danach war der Erfolg beim Einweiseln, beim „frühen Überleben“ und in der Leistung bei den im Alter von 7 Tagen eingeweiselten Königinnen sehr gering. Bis zum Einweiselalter von 24 Tagen nimmt der Erfolg zu und bleibt dann konstant. Das Modell sagte außerdem einen sehr hohen Erfolg beim Überleben und in der Leistung voraus, wenn die Königinnen im Alter von mehr als 28 Tagen eingeweiselt werden. Ähnliche Überlebens- und Leistungsdaten wurden für $\mathrm{Ge}$ schwisterköniginnen gefunden, die im Alter von 7 bis 35 Tagen in zwei weitere, nicht näher verwandte Bienenstände eingeweiselt wurden. Dies weist darauf hin, dass Bienenstand oder Bienenhaltungsmethoden nur einen geringen Einfluss auf die Überlebensrate haben. Es ergab sich ein saisonaler Effekt, hierbei waren die Überlebensraten 1999 generell geringer, die Steigungen der Kurven waren aber in allen Jahren ähnlich. Imker können daher einen ökonomischen Vorteil erwarten, wenn sie Königinnen in einem Alter von mehr als 28 Tagen einweiseln. Die Vorhersagen des Rechenmodells weisen darauf hin, dass die Überlebensrate von Königinnen, eingeweiselt im Alter von 28 Tagen, 14 Tage später $32 \%$ bzw. $8 \%$ höher liegt als bei einer Einweiselung im Alter von 14 bzw. 21 Tagen. Fünfzehn Wochen nach dem Einweiseln war die Rate $31 \%$ bzw. $10 \%$ höher. Beim Einweiseln von 35 Tage alten Königinnen zeigte sich dagegen nur eine $2 \%$ höhere Überlebensrate als bei den im Alter von 28 Tage eingeweiselten Königinnen.

Apis mellifera ligustica / Königinnenalter / Einweiselung / Überlebensrate der Königinnen

\section{REFERENCES}

Bach J.C. (1993) Bee quality discussion, Am. Bee J. 133, 479-480.

Camazine S., Cakmak I., Cramp K., Finley J., Fisher J., Frazier M., Rozo A. (1998) How healthy are commercially produced US honey bee queens? Am. Bee J. 138, 677-680.

Mangum W.A. (1997) A review of the basics and a description of the hostile worker behaviour towards the new queen, Am. Bee J. 137, 33-38.

Mathsoft (1999) S-Plus 2000 User`s Guide 1999, Data Analysis Products Division, Mathsoft, Seattle, WA, USA.

McCullagh P., Nelder J.A. (1989) Generalized Linear Models (2nd ed.), Chapman and Hall, New York.

Tarpy D.R., Hatch S., Fletcher D.J.C. (2000) The influence of queen age and quality during queen replacement in honey bee colonies, Anim. Behav. 59, 97-101. 